\title{
Evaluation of self-purifying power of cyanobacteria Pseudanabaena galeata: case of dairy factory effluents
}

\author{
Mustapha Ouhsassi ${ }^{1}$ [C El Ouardy Khay ${ }^{1} \cdot$ Abdelhakim Bouyahya $^{1,2} \cdot$ Abdeltif El Ouahrani $^{3} \cdot$ Abdellatif El Harsal $^{1}$. \\ Jamal Abrini ${ }^{1}$
}

Received: 9 July 2018 / Accepted: 22 June 2020 / Published online: 3 July 2020

(C) The Author(s) 2020

\begin{abstract}
This study aims to evaluate the treatment of wastewater from dairy plants using the self-purifying power of filamentous cyanobacterium Pseudanabaena galeata. The performance and the reliability of using cyanobacteria as wastewater treatment technique were also assessed based on total bacterial flora, total nitrogen (NK), chemical oxygen demand (COD), and total organic carbon (TOC). The results obtained show promising treatment of wastewater if $25 \%$ and $50 \%$ dilutions were applied. Thus, respectively, for 25 and 50\% dilutions, the reduction of the total bacterial flora was 67 and $45 \%$, NK removal was close to 92 and $77 \%$, the COD decreased by $77 \%$ and $65 \%$, and the TOC decreased by 78 and $77 \%$. The final concentration of cyanobacteria biomass increased from 15.72 to $585 \mathrm{mg} / \mathrm{l}$ and $475 \mathrm{mg} / \mathrm{l}$, respectively, for 25 and $50 \%$ dilutions. These results suggest that cyanobacteria (Pseudanabaena galeata) may play an effective role in the biological treatment of wastewater.
\end{abstract}

Keywords Treatment $\cdot$ Pseudanabaena galeata $\cdot$ Self-purifying $\cdot$ Wastewater $\cdot$ Diary factory

\section{Introduction}

Water resources in Morocco are limited due to the semiarid climate that characterizes most of the country that often undergoes episodic droughts. This issue is not limited to the quantity of water resources, but also to their quality, which attracts global intention more than ever nowadays (EL Addouli et al. 2009). Increasing population and industrialization are key contributors to water pollution (Rawat et al. 2011; Sood et al. 2012). These wastewaters are highly hazardous for ecosystem and human health. This issue requires a comprehensive and effective treatment before discharge into water bodies (Mishra and Mishra 2017).

Mustapha Ouhsassi

ouhsassi66@gmail.com

1 Biology and Health Laboratory, Department of Biology, Faculty of Science, Abdelmalek Essaadi University, Tetouan, Morocco

2 Laboratory of Human Pathologies Biology, Department of Biology, Faculty of Sciences, Mohammed V University, Rabat, Morocco

3 Laboratory of Applied Botany, Department of Biology, Faculty of Sciences, UAE, Tetouan, Morocco
In Morocco, domestic and industrial wastewaters are often reused without prior treatments, leading to major risk for public health such as epidemics including typhoid and cholera. The protection of public health and the environment is now the country's major concern (Darley 2002; Souabi 2007; Vasel and Jupsin 2007). Thus, wastewater treatment is becoming a priority today to reuse in agriculture, industry, and other sectors.

A number of physical, chemical, and biological methods have been developed for the treatment of wastewaters; among these, the use of microalgae is considered as an ecofriendly and low-cost approach. Biological processes for wastewater purification have shown a promising future as an alternative system for wastewater treatment (Pouliob and Notie 1985; Kong et al. 2010; Su et al. 2011).

Microalgae cultivation is an interesting approach for wastewater treatment. This approach provides tertiary biotreatment coupled with potentially interesting biomass production, which can be used for many purposes including bioenergy, pharmaceuticals, organic fertilizers, biofuels, and food for animals (Abdel-Raouf et al. 2012; Batista et al. 2015; Cai et al. 2013; Gouveia 2011; Phasey et al. 2017; Schenk et al. 2008; Renuka et al. 2015).

Cyanobacteria (green blue algae) are prokaryotic autotrophic organisms capable of surviving in adverse 
environments (wastewater). Their growth in polluted waters improves the quality of contaminated habitats. Cyanobacteria have high nitrogen and phosphorus nutrient requirements; thus, wastewaters can be used as growth media for cyanobacteria and indirectly reduce nutrient loading, making these waters useful for other applications. Apart from this, cyanobacteria have been shown to be effective in removing other contaminants such as heavy metals and inorganic and organic contaminants from various wastewaters (Sood et al. 2012). Cyanobacteria have the capacity to assimilate nutrients by phytoremediation, which refers to the dissipation of organic and inorganic compounds (carbon, nitrogen, or phosphorus), metals, and emerging contaminants from wastewater (Cuellar-Bermudez et al. 2016; Korosh et al. 2018). As a result, the integration of cyanobacteria into the wastewater treatment process seems a promising method since the removal of nitrogen and phosphorus is a key part to produce an effluent of an acceptable quality for irrigation ( Korosh et al. 2018; Liu and Vyverman 2015; Sheekh et al. 2014).

Cyanobacteria are considered promising platforms to produce high-value fuels and/or chemicals in "bio-refineries". The treatment of wastewaters by cyanobacteria is an ecological approach and a process without secondary pollution as long as the biomass produced is reused and allows efficient recycling of nutrients (Munoz and Guieysse 2008). Cyanobacteria are common in eutrophic natural waters. Favoured by warm, stable, and nutrient-enriched waters, they can be an important part of the phytoplankton community in wastewater treatment ponds. There are many benefits of using photosynthetic organisms to improve the quality of wastewaters. The oxygen produced by photosynthesis is used to reduce biological oxygen demand and refractory organic compounds (Oswald et al. 1978). The high pH values, typical of photosynthetic organism cultures, cause the depletion of coliforms and other enteric bacteria (Marais 1974). However, many cyanobacteria like Pseudanabaena galeata produce toxic compounds, presumably for self-defence. Theses cyanotoxins can affect aquatic and terrestrial wildlife and humans (Oudra et al. 2002).

However, several procedures have been developed to monitor toxins usually stored inside the cells. These procedures include sedimentation, coagulation/flocculation processes, ozonation, and filtration technologies (Miao and Tao 2009; Miao et al. 2010; Roegner et al. 2014; Romero et al. 2014).

This work aims to study the self-purifying power of cyanobacteria species (Pseudanabaena galeata), isolated from the water dams near Tetouan city (Northern Morocco). This study allows us to monitor the behaviour of this species versus the pollutant load of dairy industrial effluents and to evaluate the quality of the effluent according the national norms of industrial liquid discharge.

\section{Material and methods}

\section{Study site and sampling}

The overall objective of this study is to evaluate the behaviour and the growth mode of cyanobacteria subjected to different concentrations of wastewater of dairy liquid discharge (COLAINORD Dairy Cooperative), which produces yogurt and various dairy products.

In addition to the polluting bacterial load, this wastewater contains dairy by-products (Table 1) usually evacuated to Oued El Maleh, located north of Tetouan city (Stitou 2008). Samples were collected inside the plant before any treatment. Samples analyses were done a few hours later at the laboratory of Faculty of Sciences-Tetouan (Table 1).

\section{Biological material}

The cyanobacterium Pseudanabaena galeata used in this study (Fig. 1) was isolated from the Nakhla Dam (south of Tetouan city) and then purified in a series of axenic cultures in BG13 medium (Ferris and Hirsch (1991). The species was identified according to the work of Komárek and Anagnostidis (2005), Acinas et al. (2009) and based on its fatty acid composition (Ouhsassi et al. 2017), which is generally used as a phylogenetic marker to characterize different species of cyanobacteria (Los and Mironov 2015).

The experiments were carried out based on a series of dilutions $(25 \%, 50 \%$, and $75 \%)$ made from the raw wastewater sample mixed with Pseudanabaena galeata inoculum (ww25\% + Pseud; ww50\% + Pseud; and ww $75 \%$ + Pseud). In addition, BG130 which is a BG13 nitrogen-free and raw wastewater (ww control), both mixed with Pseudanabaena, and both were used as reference media (BG130 + Pseud; ww 100\% + Pseud) (Figs. 2, $3)$.

The Pseudanabaena galeata was previously subjected to a BG130, a free nutrient medium, for complete depletion of cell reserves prior to inoculation into wastewater samples.

Table 1 Raw contents of sampled wastewater from dairy industrial plant effluents

\begin{tabular}{lll}
\hline Parameters & Values Mini & Values Max \\
\hline Dry residue mg/l & 1000 & 3000 \\
Albumin concentration mg/l & 700 & 1800 \\
Grease mg/l & 300 & 400 \\
Lactose mg/l & 300 & 900 \\
Oxidability mg/l & 1000 & 4000 \\
\hline
\end{tabular}


Fig. 1 a Morphological image of Pseudanabaena galeata strain isolated from freshwater. $\mathbf{b}$ Pseudanabaena galeata culture in BG13 medium
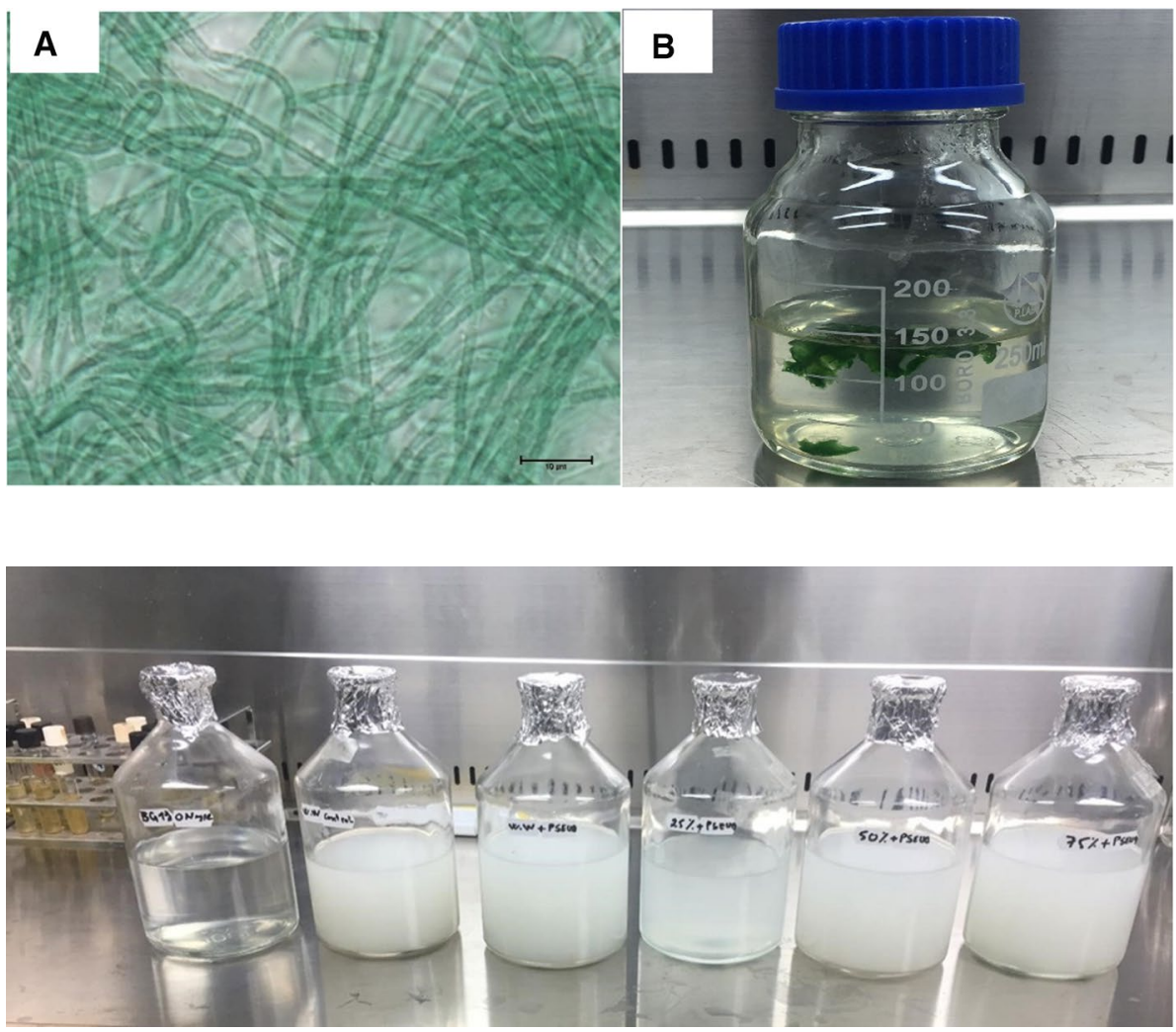

Fig. 2 Appearance of wastewater samples at the start of treatment with cyanobacteria Pseudanabaena galeata

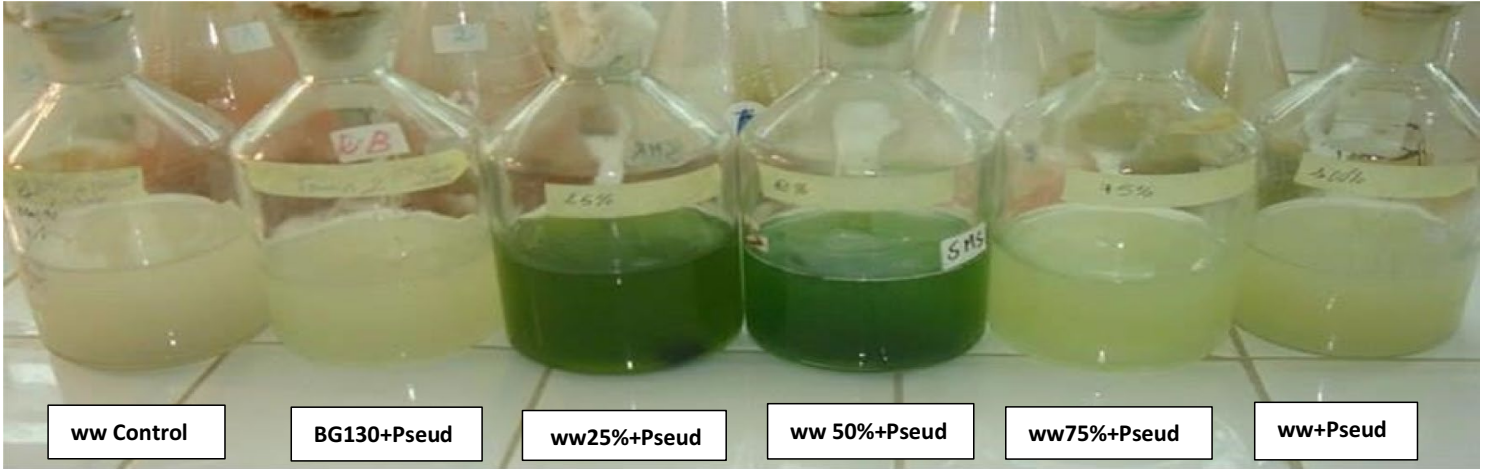

Fig. 3 Appearance of wastewater samples at the end of treatment

\section{Method used}

The study will focus on the evaluation of the following parameters:

- The monitoring of temporal evolution of the biomass produced by the cyanobacterium Pseudanabaena galeata (Fig. 4)

- Total bacterial flora (Figs. 5, 6)

- Total dissolved nitrogen (Kjeldahl nitrogen) (Fig. 7)

- Chemical oxygen demand (COD) (Fig. 8) and

- Total organic carbon (TOC) (Fig. 9).
To do this, 5\% of Pseudanabaena suspension consisting of some colonies is resuspended into 6 Erlenmeyer of $600 \mathrm{ml}$ of wastewater each. The incubations were carried out in a thermostatically controlled culture chamber at $25 \pm 1{ }^{\circ} \mathrm{C}$, aerated with a continuous supply of air, and illuminated by fluorescent white lamps with a $24-\mathrm{h}$ photoperiod 16-h day/8-h night.

Pseudanabaena galeata biomass was evaluated by the dosage of chlorophyll "a" following the method of Marker et al. (1980). 
Fig. 4 Monitoring the growth behaviour of Pseudanabaena galeata on different non-renewable culture media (wastewater control, ww $25 \%$ + Pseud, ww $50 \%+$ Pseud, ww $75 \%+$ Pseud, and ww + Pseud)
Fig. 5 Behaviour of the total bacterial flora in the presence and absence of cyanobacteria Pseudanabaena galeata on the same samples of experiment (wastewater control, ww $25 \%+$ Pseud, ww50\% + Pseud, ww $75 \%+$ Pseud, and ww + Pseud)
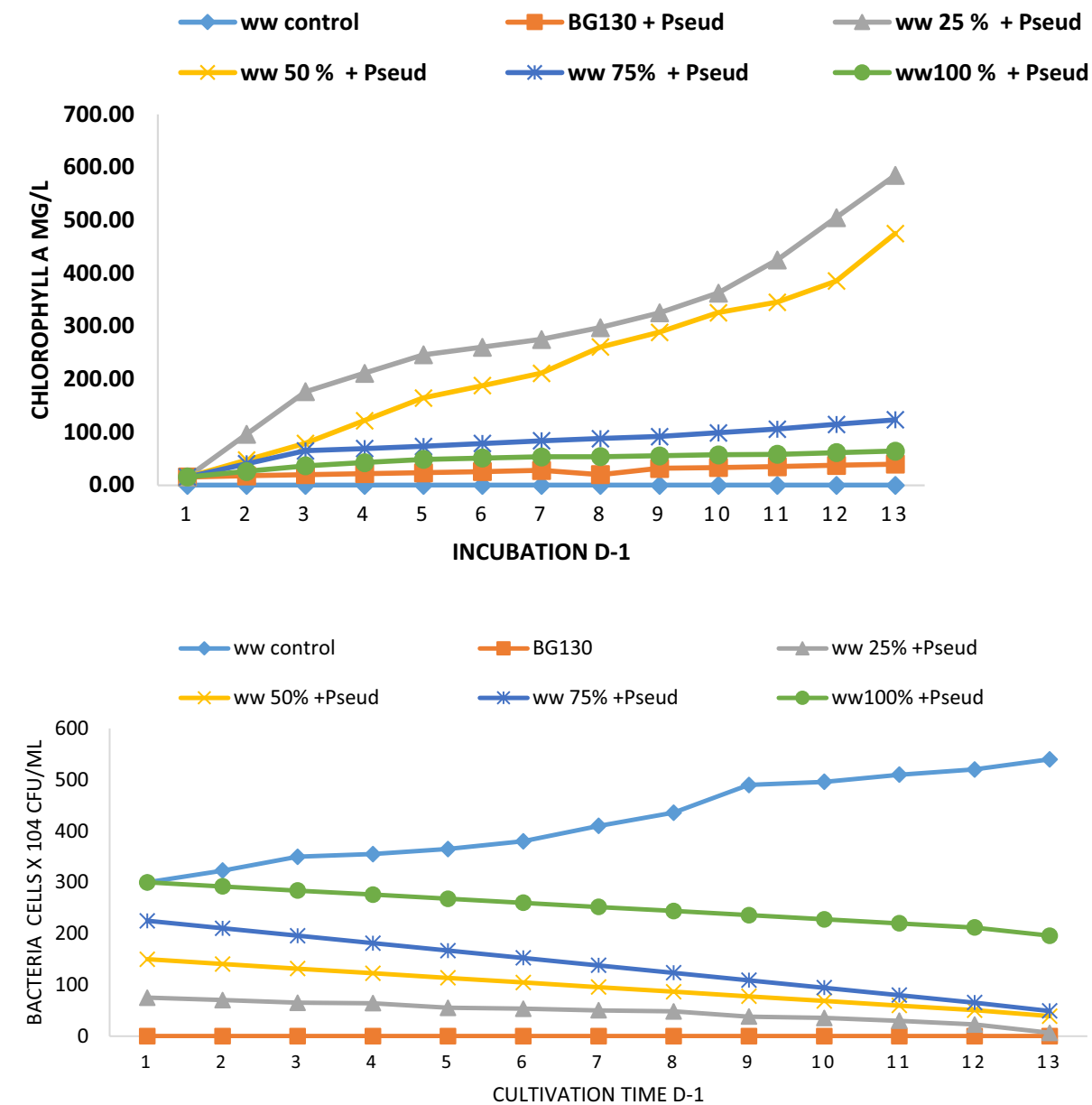

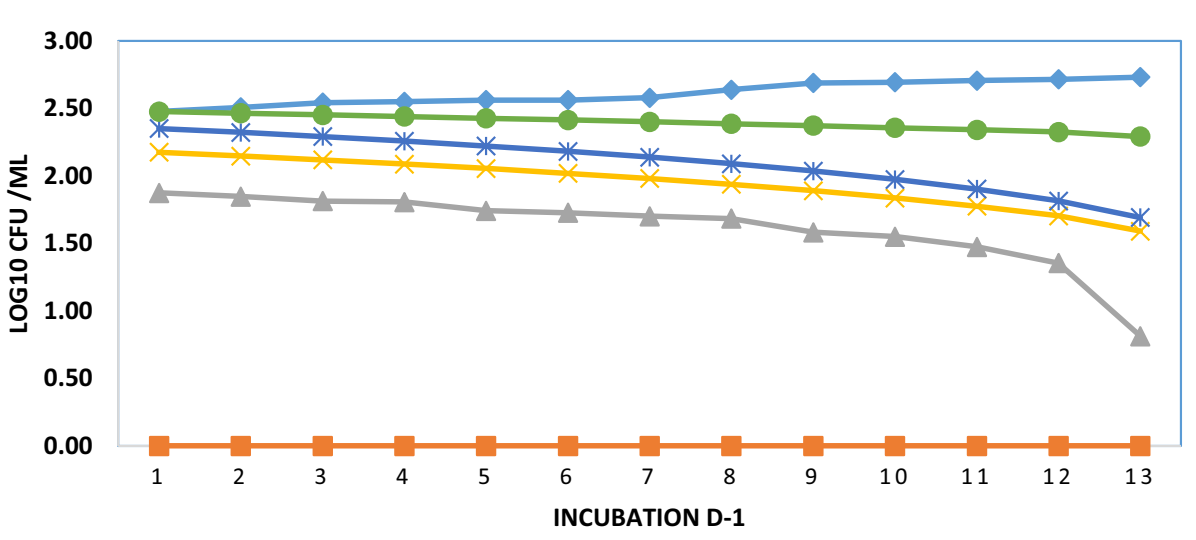

Fig. 6 Behaviour of the total bacterial flora exponential growth in the presence and absence of cyanobacteria Pseudanabaena galeata on the same samples of experiment (wastewater control, ww25\% + Pseud,ww50\% + Pseud, ww 75\% + Pseud, and ww + Pseud)

The temporal evolution of heterotrophic bacteria was enumerated, by indirect count of CFU, on nutrient (PCA) incubated at $37.5{ }^{\circ} \mathrm{C}$ for $24 \mathrm{~h}$. The rate of cell growth is determined by the formula: $\mu=\left(\left(\log _{10} N-\log _{10} N_{0}\right) 2.303\right) /\left(t-t_{0}\right)$,

where $\mathrm{N}=$ number of cells at time $\mathrm{t}$ and $\mathrm{N}_{0}$ the number of initial cells. 
Fig. 7 Removal of total nitrogen Kjeldahl on the same samples of experiment (wastewater control, ww $25 \%+$ Pseud, ww50\% + Pseud, ww $75 \%+$ Pseud, and ww $100 \%+$ Pseud)
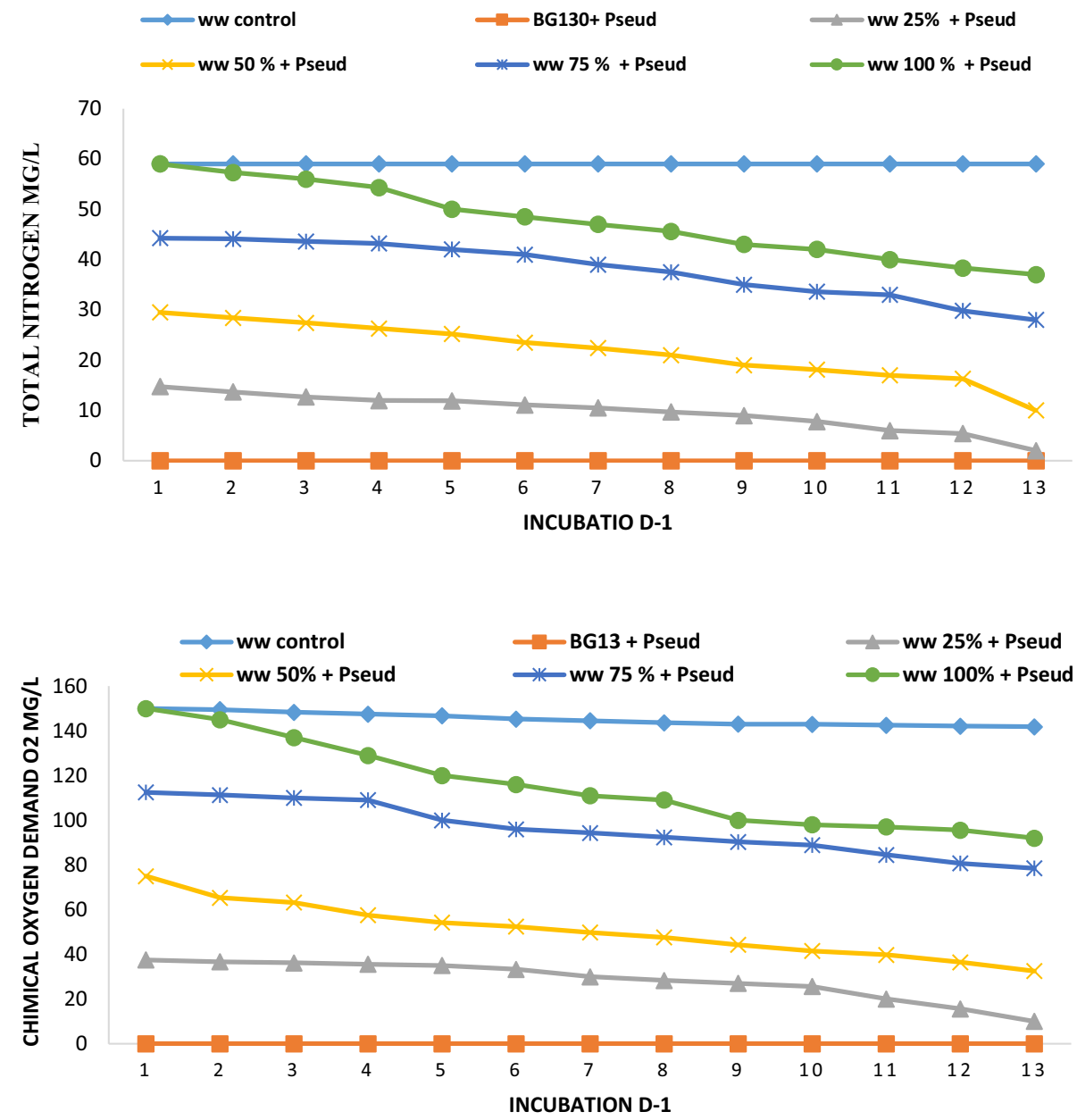

Fig. 8 Temporal changes of chemical oxygen demand on the same samples of experiment (wastewater control, ww $25 \%+$ Pseud, ww $50 \%+$ Pseud, ww $75 \%+$ Pseud, and ww100\% + Pseud)

Fig. 9 Temporal changes of dissolved total organic carbon on the same samples of experiments (wastewater control, ww $25 \%+$ Pseud, ww50\% + Pseud, ww $75 \%+$ Pseud, and ww $100 \%$ + Pseud)

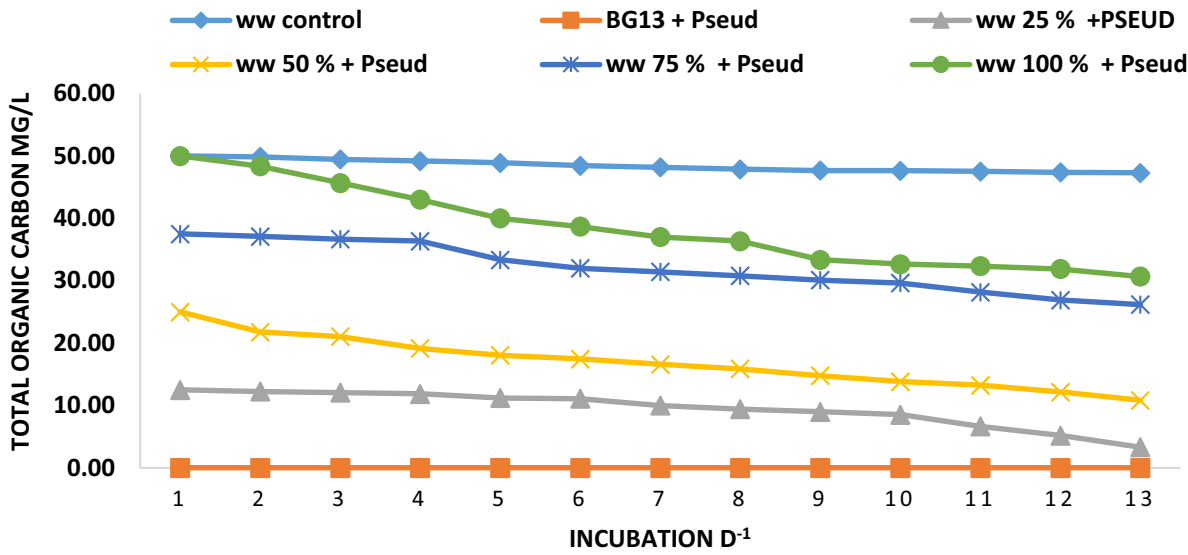

The nitrogenous matter is determined according to Kjeldahl method. This reference method is based on the transformation of organic nitrogen into inorganic nitrogen in the form of $\left(\mathrm{NH}_{4}\right)_{2} \mathrm{SO}_{4}$ by the oxidative action of sulfuric acid boiling on the organic matter and in the presence of a mineralisation catalyst. The procedure of Havilah et al. (1977), which facilitates the rapid analysis of many series of samples, is applied to products of digestion obtained from similar model as Kjeldahl method.

The COD is the amount of oxygen required for the degradation of organic matter chemically. The wastewater sample is oxidized by a hot sulfuric solution of dichromate of potassium with silver sulphate as a catalyst. Chlorides are masked by mercury sulphate. The concentration 
of green $\mathrm{Cr}^{3+}$ ions is then dosed by photometry (Rodier 2009,1996).

The total organic carbon (TOC) assessment is based on the chemical oxygen demand according to the $\mathrm{COD} / \mathrm{OC}$ ratio estimated for the bacteria, algae, organic matter released by the algae, and wastewater (Akiyama 1973; Somiya and Fujii 1984).

The data of the initial measurements of the parameters recorded on the wastewater at the beginning of the tests are prescribed in Table 2. Note that the initial Pseudanabaena inoculum of chlorophyll "a" concentration is $15.72 \mathrm{mg} / \mathrm{ml}$.

\section{Result and discussions}

\section{Growth of cyanobacteria}

After sampling from the Dam of Nakhla, $10 \mathrm{~km}$ south of Tetouan, the Pseudanabaena was purified after several treatments with BG13. The reduction of contaminating bacteria is achieved by the removal of citric acid from BG13 medium, the only source of organic carbon in this medium (Ferris and Hirsch 1991). The results obtained after 13 days of growth show an exponential growth rate of the cyanobacterial strain in most of the tested culture media with a notable growth in the case of (ww25\% + Pseud). The exponential growth rate of Pseudanabaena galeata was significantly higher $(\mathrm{p}<0.05)\left(0.30 \mathrm{~d}^{-1}\right)$ compared to other samples $\left(0.28 \mathrm{~d}^{-1}\right),\left(0.17 \mathrm{~d}^{-1}\right)$, and $\left(0.12 \mathrm{~d}^{-1}\right)$, respectively, for (ww50\% + Pseud), (ww75\% + Pseud), and (ww100\% + Pseud). For the sample (ww25\% + Pseud), the chlorophyll "a" increased from 15.72 to $585 \mathrm{mg} / \mathrm{l}$. In the case of sample (ww50\% + Pseud), the chlorophyll "a" increased from 15.72 to $475 \mathrm{mg} / \mathrm{l}$. The cell growth of Pseudanabaena under the lack of nitrogen (NK) appears to be limited (less than $40 \mathrm{mg} / \mathrm{l}$ ) in the control medium (BG130) (Fig. 4).

The high level of chlorophyll "a" was observed for the samples (ww25\% + Pseud) $(585 \mathrm{mg} / \mathrm{l})$ and (ww50\% + Pseud) $(475 \mathrm{mg} / \mathrm{l})$. The low level of chlorophyll "a" was observed in the samples (ww75\% + Pseud) $(123.55 \mathrm{mg} / \mathrm{L})$ and (ww100\% + Pseud) $(64.46 \mathrm{mg} / \mathrm{L})$. These results are in agreement with several works and studies. In fact, cells of filamentous cyanobacterium Pseudanabaena galeata can store excess quantities of nutrients, but can grow in low quantities of nutrients (Markou et al. 2014) and use their reserves in nitrogen to survive. This is consistent with the experiments of Sabour et al. (2009) who showed, as with phosphorus experiments, that cell growth of $M$. ichthyoblabe was substantially favoured under high nitrate concentrations, whereas cell growth under $\mathrm{N}$-free or $\mathrm{N}$-deficient conditions tends to be limited. It seems that Microcystis cells use their reserves in nitrogen to survive such conditions. The internal nitrogen allocations allow four days of growth for Microcystis and Synechocystis on nitrogen-deficient media. Pseudanabaena Sp. and Oscillatotia Sp. were grown in nitrogen-deficient media. The results showed that Phycobilin cells content decreased sharply for both strains (Loura et al. 1987). Nitrogen is the second most abundant element in microalgal biomass, and its content ranges from 1 up to $14 \%$ (typically around 5-10\%) of dry weight (Grobbelaar 2004).

Daniel and Aubert (1968) observed a higher growth of phytoplankton in wastewater than that obtained with the optimal artificial media. A proposed hypothesis suggested that heterotrophic bacteria produce enough growth factors/regulators for cyanobacteria to thrive in wastewater. Heterotrophic bacteria play a ubiquitous role in the growth and survival of algae (Amin et al. 2015; Gonzalez and Bashan 2000; Kim et al. 2014; Seyedsayamdost et al. 2011). They open the possibility of revisiting the global carbon cycle and other biogeochemical processes (Amin et al. 2012; Landa et al. 2015). They can activate algal growth by producing carbon dioxide (Tison and Lingg 1979; Chirac et al. 1985), vitamins, and other growth factors/regulators (Stewart and Daft 1977a, b; Hino 1984). Escher and Characklis (1982) reported that, in several aquatic environments and considering the $\mathrm{CO}_{2} / \mathrm{O}_{2}$ ratio, photosynthetic carbon fixation is limited in the aqueous phase. Microalgae such as cyanobacteria produce a large amount of oxygen $\left(0_{2}\right)$ by photosynthesis, the accumulation of which inhibits carbon fixation and consequently reduces the growth of algae (Coleman and Colman 1980). However, the reduction by heterotrophic bacteria of the tension exerted by dissolved oxygen can also be taken into account for the interpretation of the increase in algae growth. Heterotrophic bacteria degrade organic matter,
Table 2 Distribution of the initial concentrations of the different wastewater samples (ww) at the start of the analyses

\begin{tabular}{lllll}
\hline Designation & $\begin{array}{l}\text { Heterotrophic bacte- } \\
\text { ria count }(\mathrm{cfu} / \mathrm{ml})\end{array}$ & $\begin{array}{l}\text { Total nitrogen } \\
\text { Kjeldahl (NK) } \\
\mathrm{mg} / \mathrm{l}\end{array}$ & $\begin{array}{l}\text { Chemical oxygen } \\
\text { demand (COD) mg/l }\end{array}$ & $\begin{array}{l}\text { Total organic } \\
\text { carbon (TOC) } \\
\mathrm{mg} / \mathrm{l}\end{array}$ \\
\hline ww 25\% & $75 \times 104$ & 14.75 & 37.5 & 12.5 \\
ww 50\% & $150 \times 104$ & 29.5 & 75 & 25 \\
ww 75\% & $225 \times 104$ & 44.25 & 112.5 & 37.5 \\
ww 100\% (control) & $300 \times 104$ & 59 & 150 & 50 \\
\hline
\end{tabular}

لوينة مدينة الملك عبدالعزيز

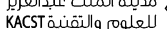


consume oxygen, and produce $\mathrm{CO} 2$ and nutrients (nitrogen and phosphorus). Lange (1973) and Wang and Priscu (1994) showed that the growth of cyanobacteria was enhanced in the presence of bacteria. Fuentes et al. (2016) suggested that massive algae production can occur in the presence of bacteria, and microalgae-bacteria interactions can be beneficial to mass production of microalgae and algal products.

\section{Removal of total bacterial flora}

The growth of heterotrophic bacteria has been affected by the presence of Pseudanabaena galeata and is progressively decreasing from 75 to $6.5 \times 10^{4} \mathrm{CFU} / \mathrm{ml}$ ( $-91.33 \%$ ), from 150 to $39 \times 10^{4} \mathrm{CFU} / \mathrm{ml}(-74 \%)$, from 225 to $49.3 \times 10^{4} \mathrm{CFU} / \mathrm{ml}(-78.08 \%)$, and from 300 to $196 \times 10^{4} \mathrm{CFU} / \mathrm{ml}(-34.66 \%)$, respectively, for (ww25\% + Pseud), (ww50\% + Pseud), (ww75\% + Pseud), and (ww100\% + Pseud). However, wastewater samples without Pseudanabaena increased from 300 to $540 \times 10^{4} \mathrm{cfu} / \mathrm{ml}(+80 \%)$ (Figs. 5, 6).

It seems that cyanobacterial secondary metabolites may act as antibacterial compounds leading to the disruption of bacterial communities and thus increases the efficiency of self-purification processes. Studies reveal that the antibacterial potential differs among cyanobacterial species, but appears to be more effective on Gram ( +) bacteria (Martins et al. 2008). Moawad (1968) found that environmental factors favourable to algal growth were unfavourable to coliform survival (Oufdou et al. 2000). Cyanobacterial exudates can stimulate or inhibit other members of the microbial community, including heterotrophic bacteria (Cole 1982; Ostensvik et al. 1998). The antimicrobial compounds found in cyanobacterial exudates include polyphenols, fatty acids, glycolipids, terpenoids, alkaloids, and a variety of bacteriocins yet to be described (Borowitzka 1995). Bacterial disintegration could be attributed to the self-purification processes carried out by Pseudanabaena galeata. The increase in $\mathrm{pH}$ associated with photosynthetic processes leads to an increase in the coliform mortality rate (El Hamouri et al. 1995; Granum and Myklestad 2002). Algae significantly reduce $E$. coli contamination in eutrophic lakes by increasing oxygenation and $\mathrm{pH}$ (Ansa et al. 2011). On the other hand, Jupsin et al. (2004) stated that the combined effect of light, $\mathrm{pH}$, and temperature improves the elimination of bacteria. In addition, nutrient competition in discontinuous environments can reduce the growth rate of bacteria. Nevertheless, our results were in agreement with the work of (Lange 1973), who showed that cultures of various cyanobacteria were improved in the presence of bacteria.

\section{Removal of total nitrogen}

The experimental results show that the total nitrogen concentrations decreased progressively and proportionally with the production of algal biomass. In fact, it decreased from 14.75 to $2 \mathrm{mg} \mathrm{N} / 1$ ( $-86.44 \%), 29.5$ to $10 \mathrm{mg} \mathrm{N} / \mathrm{l}(-66.1 \%), 44.25$ to $28 \mathrm{mg} \mathrm{N} / \mathrm{l}(-36.72 \%)$, and 59 to $37 \mathrm{mg} \mathrm{N} / 1(-37.28 \%)$, respectively, for (ww25\% + Pseud), (ww50\% + Pseud), (ww75\% + Pseud), and (ww100\% + Pseud) (Fig. 7). Liu and Vyverman (2015) indicated that Pseudanabaena sp. was highly suitable for removing nitrogen from wastewaters with high N/P ratio. The Pseudanabaena galeata strain uses the nitrogen to satisfy their needs for growth and survival. de la Noue and Basseres (1989) and Rasoul-Amini et al. (2014) suggested that the nearly total depletion of total nitrogen in a domestic wastewater culture medium was mainly attributed to algal consumption. Meanwhile, the degradation of organic compounds containing nitrogen by microalgae-bacteria consortia was significantly higher, and the nitrogen released was assimilated by the microalgae (Subashchandrabose et al. 2011). In this study, the best yield is observed for the case of (ww25\% + Pseud) sample which recorded an assimilation of the dissolved nitrogen of 14.75 to $2 \mathrm{mg} \mathrm{N} / \mathrm{ml}(-86.44 \%)$.

\section{Chemical oxygen demand reduction}

Chemical oxygen demand (COD) is one of the parameters for measuring the quality of wastewater. It represents the amount of oxygen needed to oxidize all the organic matter in the water. The effect of Pseudanabaena galeata on COD reduction was carried out 13 days continuously. Figure 8 shows that the degradation process of the organic matter is expressed by a progressive decrease in the COD as a function of time for all the samples of experiment. Respectively, this recorded decrease was 37.5-10 $\mathrm{mgO} 2 / \mathrm{l}(-73.33 \%)$; $75-32.5 \mathrm{mgO} 2 / \mathrm{l}$ (- 56.66\%); 112.5-78.5 mgO2/1 (-30.22\%); 150-92 mgO2/l (-38.66\%); and 150-141.8 $\mathrm{mgO} 2 / \mathrm{l}(-5.46 \%)$ for (ww25\% + Pseud), (ww50\% + Pseud), (ww75\% + Pseud), (ww100\% + Pseud), and (ww control).

The decrease in COD can be explained by the transformation of organic matter in the form of algal biomass (Nacir et al. 2010).

\section{Reduction of total organic carbon (TOC)}

Total organic carbon (TOC) is defined as any compound containing carbon atoms, except $\mathrm{CO} 2$, such as carbonate and bicarbonate (Chou et al. 2010; Mook et al. 2012). Implementing (TOC) analysis at water treatment facilities is a

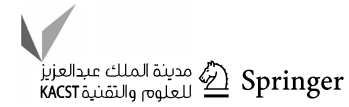


powerful tool that can help operators continue to effectively treat water and positively affect the costs of treatment, in order to meet current and future regulatory requirements. The major compositions of dissolved organic carbon in aquaculture wastewater are humic-like substances, carbohydrates, protein-like substances, low molecular weight aldehydes, fulvic acids, phenols, and organic peroxides (Mostofa et al. 2005). Organic carbon is the energy substrate for many microorganisms. In our case study, TOC levels are gradually decreased in all samples (Fig. 9). The values of TOC were decreased as follows: from 12.5 to $3.33 \mathrm{mgO} 2 / \mathrm{l}(-73.36 \%)$ for (ww25\% + Pseud); from 25 to $10.83 \mathrm{mgO} 2 / \mathrm{l}(-56.68 \%)$ for (ww50\% + Pseud); from 37.5 to $26.17 \mathrm{mgO} 2 / \mathrm{l}(-30.21 \%$ ) for (ww75\% + Pseud); from 50 to $30.67 \mathrm{mgO} 2 / \mathrm{l}(-38.66 \%$ ) for ( $\mathrm{ww}+$ Pseud); and from 50 to $47.27 \mathrm{mgO} 2 / \mathrm{l}(-5.46 \%)$ for (ww control).

These results are in agreement with the work of Houas et al. (2001) who showed that the treatment of domestic water by algae leads to a reduction of total organic carbon.

\section{Conclusion}

In conclusion, this work allows the verification of the filamentous cyanobacterium Pseudanabaena galeata strain selfpurifying capacity of dairy plant wastewater. This capacity is reflected by the increase in cyanobacterial biomass due to its adaptive potentiality to growth in this type of nutrientrich medium. In addition, it allows the reduction of COD and TOC, removal of total nitrogen, and inhibition of total bacterial flora. It should be pointed out that the dilution of the effluent before the treatment is an important factor regulating the self-purifying power of cyanobacteria. As a result, Pseudanabaena galeata can play a potential key role in the purification of wastewater from industrial effluents.

Open Access This article is licensed under a Creative Commons Attribution 4.0 International License, which permits use, sharing, adaptation, distribution and reproduction in any medium or format, as long as you give appropriate credit to the original author(s) and the source, provide a link to the Creative Commons licence, and indicate if changes were made. The images or other third party material in this article are included in the article's Creative Commons licence, unless indicated otherwise in a credit line to the material. If material is not included in the article's Creative Commons licence and your intended use is not permitted by statutory regulation or exceeds the permitted use, you will need to obtain permission directly from the copyright holder. To view a copy of this licence, visit http://creativecommons.org/licenses/by/4.0/.

\section{References}

Abdel-Raouf N, Al-Homaidan AA, Ibraheem IBM (2012) Microalgae and wastewater treatment. Saudi J Biol Sci 19:257-275
Acinas SG, Haverkamp TH, Huisman J, Stal LJ (2009) Phenotypic and genetic diversification of Pseudanabaena spp. (cyanobacteria). ISME J 3:31-46

Akiyama T (1973) Index of water pollution and their application. Wat Purif Liquid Waste Treat 14:361-368

Amin SA, Parker MS, Armbrust EV (2012) Interactions between diatoms and bacteria. Microbiol Mol Biol Rev 76:667-684

Amin SA, Hmelo LR, vanTol HM, Durham BP, Carlson LT, Heal KR (2015) Interaction and signalling between a cosmopolitan phytoplankton and associated bacteria. Nature 522:98-101

Ansa EDO, Lubberding HJ, Ampofo JA, Gijzen HJ (2011) The role of algae in the removal of Escherichia coli in a tropical eutrophic lake. Ecol Eng 37:317-324

Batista AP, Ambrosano L, Graca S, Sousa C, Marques PA, Ribeiro B (2015) Combining urban waste wáter treatment with biohydrogen production Anintegrated microalgae-based approach. Bioresour Technol 184:230-235

Borowitzka MA (1995) Microalgae as sources of pharmaceuticals and other biologically active compounds. J Appl Phycol 7:65-68

Cai T, Park SY, Li Y (2013) Nutrient recovery from wastewater streams by microalgae: Status and prospects. Renew Sust Ener Rev 19:360-369

Chou WL, Wang CT, Hsu CW, Huang KY, Liu TC (2010) Removal of total organic carbon from aqueous solution containing polyvinyl alcohol by electrocoagulation technology. Desalination 259(1-3):103-110

Cole JJ (1982) Interactions between bacteria and algae in aquatic ecosystems. Annu Rev Ecol Syst 13:291-314

Coleman JR, Colman B (1980) Effect of oxygen and temperature on the efiïciency of photosynthetic carbon assimilation in two microscopic algae. Plant Physiol 65:980-983

Cuellar-Bermudez SP, Aleman-Nava GS, Chandra R, Garcia-Perez JS, Contreras-Angulo JR, Markou G, Parra-Saldivar R (2016) Nutrients utilization and contaminants removal. A review of two approaches of algae and cyanobacteria in wastewater. Algal Res 24:438-449

Chirac C, Casadevall E, Largeau C, Metzger P (1985) Bacterial influence upon growth and hydrocarbonproduction of the green alga Botrycoccusbraunii. J Phycol 21:380-387

Daniel S, Aubert M (1968) Eaux résiduaires et Plancton. Rev Intern Méd 10:93-110

Darley J (2002) Traitement et réutilisation des eaux usées urbaines. Synthèse des travaux de recherches scientifiques de la Faculté des Sciences Semlalia à Marrakech et applications pratiques

de la Noue J, Basseres A (1989) Biotreatment of anaerobically digested swine manure with microalgae. Biol Wastes 29:17-31

EL Addouli J, Chahlaoui A, Berrahou A, Chafi A, Ennabili A, Karrouch L (2009) Influence de rejects d'eaux usées sur les qualités physicochimique et bactériologique d'eaux utilisées en irrigation, déchets. Revue francophone d'écologie industrielle $56: 23-28$

EI Hamouri B, Jellal J, Outabiht H, Nebri B, Khallayoune K, Benkerroum A, Hajli A, Firadi R (1995) The performance of high-rate algal pond in the Moroccan climate. Wat Sci Technol 31:67-74

El Sheekh MM, ELShouny WA, Osman ME, El Gammal EW (2014) Treatment of sewage and industrial wastewater effluents by the cyanobacteria Nostocmuscorum and Anabaena subcylinderica. J Water Chem Technol 36:190-197

Escher A, Characklis WG (1982) Algal-bacterial interactions within aggregates. Biotechnol Bioengng 24:2283-2290

Ferris JM, Hirsch CF (1991) Method for isolation and purification of Cyanobacteria. Appl Environ Microbiol 57:1448-1452

Fuentes JL, Garbayo I, Cuaresma M, Montero Z, González-del-Valle M, Vílchez C (2016) Impact of microalgae-bacteria interactions on the production of algal biomass and associated compounds. Mar Drugs 14:100 
Gonzalez LE, Bashan Y (2000) Increased growth of the microalga Chlorella vulgaris when coimmobilized and cocultured in alginate beads with the plant-growth-promoting bacterium Azospirillumbrasilense. Appl Environ Microbiol 66:1527-1531

Gouveia L (2011) Microalgae as a Feedstock for Biofuels. Springer, Berlin Heidelberg, pp 1-69

Grobbelaar JU (2004) Algal nutrition. In: Richmond A (ed) Handbook of microalgal culture: biotechnology and applied phycology. Blackwell Publishing, Oxford, pp 97-115

Granum E, Myklestad SM (2002) A photobioreactor with pH control: demonstration by growth of the marine diatom Skeletonemacostatum. J Plankton Res 24:557-563

Havilah EJ, Wallis DM, Morris R, Woolnough JA (1977) A microcolorimetric method for determination of ammonia in kjeldahl digests with a manual spectrophotometer. Lab Pract. pp 545-547

Hino S (1984) Algal stimulation by heterotrphic bacteria with lake sédiment extract. Jap J Phycoi 32:124-129

Houas A, Lachheb H, Ksibi M, Elaloui E, Herrmann JM (2001) Photocatalytic degradation pathway of methylene blue in water. Appl Catal B 31:145-157

Kim B-H, Ramanan R, Cho D-H, Oh H-M, Kim H-S (2014) Role of Rhizobium, a plant growth promoting bacterium, in enhancing algal biomass through mutualistic interaction. Biomass Bioeng 69:95-105

Komarek J, Anagnostidis K (2005) Cyanoprokaryota, freshwater flora of Central Europe. Gustav Fischer, Jena Stuttgart Lübeck Ulm., p 548

Kong Q, Li L, Martinez B, Chen P, Ruan R (2010) Culture of microalgae Chlamydomonasreinhardtii in wastewater for biomass feedstock production. Appl Biochem Biotechnol 160:9-18

Korosh TC, Dutcher A, Pfleger BF, McMahon KD (2018) Inhibition of cyanobacterial growth on a municipal wastewater sidestream is impacted by temperature

Landa M, Blain S, Christaki U, Monchy S, Obernosterer I (2015) Shifts in bacterial community composition associated with increased carbon cycling in a mosaic of phytoplankton blooms. ISME J

Lange W (1973) Bacteria-assimiliable organic compounds, phosphate, and enhanced growth of bacteriaassociatedblue-green algae. J Phycol 9:507-509

Liu J, Vyverman W (2015) Differences in nutrient uptake capacity of the benthic fi lamentous algae Cladophora sp., Klebsormidium sp. and Pseudanabaena sp. under varying N/P conditions. Bioresource Technol 179:234-242

Los DA, Mironov KS (2015) Modes of fatty acid desaturation in cyanobacteria: an update. Life 5:554-567

Loura IC, Dubacq JP, Thomas JC (1987) The effects of nitrogen deficiency on pigments and lipids of cyanobacteria. Plant Physiol. 83:838-843

Marais GR (1974) Fecalbacteriakinetics in stabilization ponds. J Environ Eng Div Proc Am Sot Civ Eng 100:119-139

Miao H, Tao W (2009) The mechanisms of ozonation on cyanobacteria and its toxins removal. Sep Purif Technol 66:187-193

Miao HF, Qin F, Tao GJ, Tao WY, Ruan WQ (2010) Detoxification and degradation of microcystin-LR and -RR by ozonation. Chemosphere 79:355-361

Mishra N, Mishra N (2017) Utilization of microalgae for integrated biomass production and phycoremediation of wastewater. J Algal Biomass Utln 8:95-105

Marker AFH, Crowther CA, Gunn RJM (1980) Methanol and acetone as solvents for estimating chlorophyll a and phaeopigments by spectrophotometry. Arch.Hydrobiol./Beih. Ergenb Limnol 14:52-69

Markou G, Vandamme D, Muylaert K (2014) Microalgal and cyanobacterial cultivation: The supply of nutrients. Water Res 65:186-202
Martins RF, Ramos MF, Herfindal L, Sousa K, Skærven JA, Vasconcelos VM (2008) Antimicrobial and cytotoxic assessment of marine cyanobacteria-Synechocystis and Synechococcus. Mar Drugs $6: 1-11$

Moawad SK (1968) Inhibition of coliform bacteria by algal population in microoxidation ponds. Environ Health 10:106-112

Mook WT, Chakrabarti MH, Aroua MK, Khan GMA, Abu Hassan MA (2012) Removal of total ammonia nitrogen (TAN), nitrate and total organic carbon (TOC) from aquaculture wastewater using electrochemical technology. Desalination 285:1-13

Mostofa KMG, Honda Y, Sakugawa H (2005) Dynamics and optical nature of fluorescent dissolved organic matter in river waters in Hiroshima Prefecture, Japan. Geochem J 39:257-271

Munoz R, Guieysse B (2008) Algal-bacterial processes for the treatment of hazardous contaminants: a review. Water Res 40:2799-2815

Nacir S, Ouazzani N, Vasel J, Jupsin H, Mandi L (2010) Traitement des eaux usées domestiques par un chenal algal à haut rendement (CAHR) agité par air lift sous climat semi-aride. Revue des sciences de l'eau 23:57-72

Oudra B, Loudiki M, Vasconcelos V, Sabour B, Sbiyyaa B, Oufdou K, Mezrioul N (2002) Detection and quantification of microcystins from cyanobacteria strains isolated from reservoirs and ponds in Morocco. Environ Toxicol 17(1):32-39

Oufdou K, Mezrioul N, Oudra B, Barakate M, Loudiki M, Alla AA (2000) Relationship between bacteria and cyanobacteria in the Marrakech waste stabilization ponds. Water Sci Technol 42:171-178

Ouhsassi M, Khay EL, Bouyahya A, Abrini J (2017) Isolation and characterization of cyanobacteria strains based on the compositional approach of fatty acids: case of drinking water reservoirs in the region of Tetouan (Northern Morocco)J. Algal Biomass Utln 9:57-67

Ostensvik O, Skulberg OM, Underal B, Hormazabal V (1998) Antibacterial properties of extracts from selected planktonic freshwater cyanobacteria: a comparative study of bacterial bioassays. J Appl Microbiol 84:1117-1124

Oswald WJ, Lee EW, Adan B, Yaok H (1978) New waste water treatment method yields a harvest of sale-able algae. WHO Chron 32:349-350

Phasey J, Vandammec D, Fallowfield HJ (2017) Harvesting of algae in municipal wastewater treatment by calcium phosphate precipitation mediated by photosynthesis, sodium hydroxide and lime. Algal Res 27:115-120

Pouliob Y, De la Notie J (1985) Utilisation des micro-algues pour le traitementtertiaire des eauxuseés. C.R. $7^{\mathrm{e}}$ Symp.Traitement Eaux Useés. University Laval. Montreal, pp. 131-145

Rawat I, Kumar RR, Mutanda T, Bux F (2011) Dual role of microalgae: phycoremediation of domestic wastewater and biomass production for sustainable biofuels production. Appl Energy 88:3411-3424

Rasoul-Amini S, Montazeri-Najafabady N, Shaker S, Safari A, Kazemi A, Mousavi P, Mobasher MA, Ghasemi Y (2014) Removal of nitrogen and phosphorus from wastewater using microalgae free cells in bath culture system. Biocatal Agric Biotechnol 3:126-131

Renuka N, Sood A, Prasanna R, Ahluwalia AS (2015) Phycoremediation of wastewaters: a synergistic approach using microalgae for bioremediation and biomass generation. Int J Environ Sci Technol 12:1443-1460

Rodier J et al (2009) L'analyse de l'eau, 9e édition. DUNOD (éditeur), Paris, France, p 1579

Rodier J (1996) L'analyse de l'eau: eaux naturelles, eaux résiduaires, eaux de mer, chimie, physicochimie, microbiologie, biologie, interprétation des résultats. Dunod, p, Paris (France), p 1384 
Romero LG, Mondardo RI, Sens ML, Grischek T (2014) Removal of cyanobacteria and cyanotoxins during lake bank filtration at Lagoa do Peri, Brazil, Clean Technol. Environ, pp 1133-1143.

Roegner AF, Brena B, González-Sapienza G, Puchner B (2014) Microcystins in potable surface waters: toxic effects and removal strategies. J Appl Toxicol 34:441-445

Sabour B, Loudiki M, Vasconcelosc V (2009) Growth responses of Microcystis ichthyoblabe Kützing and Anabaena aphanizomenoides Forti (cyanobacteria) under different nitrogen and phosphorus conditions. Chem Ecol 25(5):337-344

Seyedsayamdost MR, Case RJ, Kolter R, Clardy J (2011) The Jekylland-Hyde chemistry of Phaeobacter gallaeciensis. Nat Chem 3:331-335

Souabi S (2007) Gestion des ressources en eau au Maroc. Université Mohammed Premier, Oujda, Maroc, Congrès international Eau et Déchets

Somiya I, Fujii S (1984) Material balances of organics and nutrients in an oxidation pond. Water Res 18:325-333

Sood A, Uniyal PL, Prasanna R, Ahluwalia AS (2012) Phytoremediation potential of aquatic macrophyte, Azolla. Ambio 41:122-137

Sood A, Renuka N, Prasanna R, Ahluwalia AS (2015) Cyanobacteria as potential options for wastewater treatment. In: Ansari A, Gill S, Gill R, Lanza G, Newman L

Schenk P, Thomas-Hall S, Stephens E, Marx U, Mussgnug J, Posten C, Kruse O, Hankamer B (2008) Second generation biofuels: highefficiency microalgae for biodiesel production. Bio EnergyRes $1: 20-43$

Stewart WDP, Daft MJ (1977a) Microbial pathogens of cyanophycean blooms. In: Droop MR, Jannasch JW (eds) Advances in aquatic microbiology. Academic Press, London, pp 177-218
Stitou A (2008) Impact des rejets industriels sur la qualité de l'oued martil, Revue AFN Maroc. 30-36.

Stewart WDP, Daft MJ (1977b) Microbial pathogens of Cyanophycean blooms. In: Droop MR, Jannasch JW (eds) Advances in aquatic Microbiology. Academic Press, London, pp 177-218

Subashchandrabose SR, Ramakrishnan B, Megharaj M, Venkateswarlu K, Naidu R (2011) Consortia of cyanobacteria/microalgae and bacteria: biotechnological potential. Biotechnol Adv 29(6):896-907

Su Y, Mennerich A, Urban B (2011) Municipal wastewater treatment and biomass accumulation with a wastewater-born and settleable algal-bacterial culture Water Res 45:3351-3358

Tison D, Lingg AJ (1979) Dissolved organic matter utilization and oxygen uptake in algal-bacterial microcosms. Can J Microbiol 25(11):1315-1320

Vasel JL, Jupsin H (2007) Etat de l'art et perspectives des techniques extensives d'épuration des eaux usées domestiques sous climat aride. Université Mohammed Premier, Oujda, Maroc, Congrès international Eau et Déchets

Wang L, Priscu JC (1994) Stimulation of aquatic bacterial activity by Cyanobacteria. Hydrobiologia 277:145-158

Publisher's Note Springer Nature remains neutral with regard to jurisdictional claims in published maps and institutional affiliations. 